\title{
The Foreign Exchange Exposure of ChInESE Banks
}

\author{
Tak-Chuen Wong ${ }^{*+}$, Jim Wong ${ }^{*}$, and Phyllis Leung ${ }^{*}$
}

\begin{abstract}
Using the capital market approach and the equity price data of 14 listed Chinese banks, this empirical study finds that there is a positive relationship between bank size and foreign exchange exposure. This relationship may reflect the larger foreign exchange operations and trading positions of larger Chinese banks and their significant indirect foreign exchange exposure arising from impacts of the renminbi exchange rate movements on their customers. Empirical evidence also suggests that the average foreign exchange exposures of state-owned and joint-stock commercial banks in China are higher than those of banks in Hong Kong, notwithstanding their limited participation in international banking businesses compared with their Hong Kong counterparts. It is also found that negative foreign exchange exposure is prevalent for larger Chinese banks, suggesting that an appreciation of the renminbi tends to reduce their equity value. It is therefore likely that the banking sector's performance will be hampered. Together with the fact that decreases in equity values generally imply a higher default risk, the effects of different scenarios of renminbi appreciation on the default risk of Chinese banks should therefore be closely monitored.
\end{abstract}

JEL Classification Numbers: E58; F31; G21; G28

Keywords: Foreign exchange policy; Foreign exchange risk; Banking; China

\footnotetext{
+ Corresponding Author

* The views and analyses expressed in the paper are those of the authors, and do not necessarily represent the views of the Hong Kong Monetary Authority. The authors would like to thank Hans Genberg, Cho-Hoi Hui, Yongmiao Hong, the participants of the sixth Hong Kong Institute for Monetary Research China Workshop, and the anonymous referee for their useful comments and suggestions. All remaining errors are the authors' own. Author contact: Market Research Division, Research Department, Hong Kong Monetary Authority, 55/F, Two International Finance Centre, 8, Finance Street, Central, Hong Kong, China. Email: Etcwong@hkma.gov.hk; Jim_HY_Wong@hkma.gov.hk; Plyleung@hkma.gov.hk, Phone: (852) 28788735 Fax: (852) 28781891.
} 


\section{INTRODUCTION}

Foreign exchange rate movements could be an important source of risk for banking institutions. ${ }^{1}$ In a worst-case scenario, large foreign exchange losses could lead to bank failures. $^{2}$ Even for a mild scenario, foreign exchange losses could cause huge burdens on banks' profitability. Due to their serious implications for risk management and banking sector stability, measuring banks' foreign exchange exposure has long been a core interest of risk management professionals, academics, and central banks.

In the literature, a large number of empirical works have been carried out to examine the foreign exchange exposure of banks. However, past studies mainly focused on large banking institutions (Martin (2000)) or banking markets that are well developed, including the US (Grammatikos et al. (1986), Choi et al. (1992), Choi and Elyasiani (1997), and Martin and Mauer (2003, 2005)), Japan (Chamberlain et al. (1997)), Canada (Atindéhou and Gueyie (2001)), and Australia (Chi et al. (2007)). By comparison, studies focusing on less developed banking markets are relatively scant. ${ }^{3}$

For China's banking sector, the growing internationalisation of Chinese banks in both their fundraising activities and banking businesses and the lack of financial instruments available in the local market for Chinese banks to hedge their foreign exchange risk, together with the structural change in China's exchange rate regime in July 2005, may suggest that Chinese banks in general have become increasingly exposed to

Reflecting this, most banks have been required to measure and apply regulatory capital charges with respect to their foreign exchange risk since the issuance of Basel (1996).

2 For example, the failure of Franklin National Bank of New York in 1974 in the US and the liquidation of Bankhaus (I.D.) and Herstatt KG in 1974 in West Germany. For details, see Aharony and Swary (1983).

3 There were only a few studies on less developed banking markets, such as Hahm (2004) on the Korean banking market and de Wet and Gebreselasie (2004) on the African banking market. 
foreign exchange risk. Given this situation, a comprehensive empirical study on the foreign exchange exposure of Chinese banks could provide useful insights for both exchange rate and banking policies in China.

However, partly due to the lack of data, past analyses on the foreign exchange exposure of Chinese banks are rather primitive, mainly focused on the quantification of foreign exchange exposure arising from the banks' unhedged foreign assets and liabilities (i.e., direct or accounting exposures). As shown by Chamberlain et al. (1997), to the extent that banks' direct exposure generally provides a significant explanation for banks' foreign exchange exposure, it nonetheless only measures banks' foreign exchange risk partially. Using a bank's loan to an exporter as an example, Chamberlain et al. (1997) demonstrate that banks that perfectly hedge their accounting exposure could still be exposed to significant foreign exchange risk if exchange rate movements affect cash flows, competitiveness, and credit risk of the banks' customers significantly (i.e., indirect or economic exposures). ${ }^{4}$ This indicates that the foreign exchange risk sources of banks are far more than just their net foreign assets holdings.

As for the identification of foreign exchange exposure of individual banks, while the direct exposure can be discerned largely from their accounting data, the indirect exposure, which arises from impacts of exchange rate fluctuations on the economy in general and the banks' customers in particular, takes more subtlety to identify from these data. Therefore, past analyses on the foreign exchange exposure of Chinese banks may not have been able to give a comprehensive picture of how Chinese banks are exposed to

4 For an exporter in the US, if the US dollar appreciates, then the competitiveness of the exporter may deteriorate, which would imply a higher default risk for the exporter. The bank that lends money to this exporter is therefore indirectly exposed to foreign exchange exposure. For details, see footnote 18 of Chamberlain et al. (1997). 
foreign exchange risk. This is particularly true given that the indirect foreign exchange exposure of Chinese banks appears to be a significant, or even a dominant, component of their overall foreign exchange exposure, as Chinese banks generally have a significant portion of loans that are related to export-import activities, such as lending to the manufacturing industry, the competitiveness and profitability of which are sensitive to exchange rate movements.

With the increased availability of time series and cross-section data for Chinese banks' equity prices, as a result of the listing of a number of major state-owned Chinese banks in stock markets since mid-2005, it has now become possible to investigate the overall foreign exchange exposure (comprising all direct and indirect foreign exchange exposures) of the Chinese banking sector more accurately and comprehensively using the capital market approach. Compared with the cash flow approach, another commonly adopted approach which is based on banks' financial statements data, the capital market approach has various advantages. Specifically, estimates from the capital market approach are forward looking and facilitate analyses of Chinese banks' default risk. More importantly, it remedies the problem of a lack of observations in the cash flow approach. Owing to these advantages, the capital market approach is chosen in this study. ${ }^{5}$

Using the capital market approach and the equity price data of 14 listed Chinese banks in the Chinese stock market (i.e., A-share market) and the Hong Kong stock market (i.e., H-share market), this study attempts to investigate the overall foreign exchange exposure of Chinese banks individually.

Comprehensive review of these two empirical approaches on banking studies can be found in Martin and Mauer (2005). It should be noted that these two approaches are also widely applied for studying other industries, see Muller and Verschoor (2006). 
The remainder of the paper is organised as follows. Sections II and III describe empirical specifications and data and estimation methods, respectively. Section IV presents estimation results. Section V concludes.

\section{The EMPIRICAL SPECIFICATION}

Past empirical studies using the capital market approach to study foreign exchange risk of banks , such as Choi et al. (1992), Wetmore and Brick (1994), and Choi and Elyasiani (1997), are essentially based on the following asset pricing model with different modifications,

$$
R_{n, t}-R F_{t}=\alpha_{n}+\beta_{n}^{m}\left(R_{m, t}-R F_{t}\right)+\beta_{n}^{I} I_{t}+\beta_{n}^{X} X_{t}+\varepsilon_{n, t}
$$

where $R_{n, t}$ and $R F_{t}$ are the holding period rate of return of the $n^{\text {th }}$ bank stock from $t-1$ to $t$ and the risk-free interest rate at time $t$, respectively, and $\left(R_{m, t}-R F_{t}\right)$ is the excess rate of return of the market portfolio. The other two risk factors, $I_{t}$ and $X_{t}$, represent the rate of change in the yield of a risk-free bond ${ }^{6}$ from $t-1$ to $t$, and that of the exchange rate, respectively. $\varepsilon_{n, t}$ is a risk component for the $n^{\text {th }}$ bank related to other risks and measurement errors.

6 In the literature, various alternative interest rate variables are frequently adopted to estimate the interest rate sensitivity of banks' equity returns. For example, Flannery and James (1984) separately use the rate of change in the yield of 7-year Treasury bonds and the rate of change in the price of 1-year Treasury bills as a proxy for the interest rate variable. They show that commercial bank stock returns in the US are sensitive to interest rate changes no matter which interest rate variable is employed. For empirical studies of the sensitivity of bank stock returns to interest rates, see also Bae (1990) and Chen and Chan (1989). 
Although the empirical specification in Equation (1) is widely applied in past empirical studies to estimate foreign exchange exposure of banks, it is not without drawbacks. Various theories and empirical evidence suggest that the specification in Equation (1) could be extended and improved. In the first part of this section, the relevant theoretical and empirical considerations for model specifications will be discussed. Different empirical specifications for dual-listed Chinese banks and locally listed Chinese banks which incorporate relevant theoretical and empirical considerations will be given in the latter part of this section.

For the market risk sensitivity, $\beta_{n}^{m}$, the specification in Equation (1) assumes that only the return of the market portfolio where a bank is listed affects the bank's stock return. However, this assumption may not be appropriate for dual-listed firms. Theoretically, the expected return of a dual-listed firm depends not only on the return of the domestic market portfolio, but also on the return of the foreign market portfolio (See Alexander et al. (1987)). Empirically, using daily equity price data for 16 dual-listed Chinese stocks (in A- and H-share markets) for the period of June 1995 to September 2001, Wang and Jiang (2004) find that the H-shares of Chinese stocks are exposed significantly to both the Hong Kong and Chinese stock markets, which is consistent with the asset pricing theory for dual-listed firms. ${ }^{7}$ This result is also consistent with the fact that $\mathrm{H}$ share investors in Hong Kong theoretically bear significant country risk to China due to the fact that the $\mathrm{H}$-share companies to a large extent operate mainly in China rather than in Hong Kong. As the six largest listed Chinese banks are dual-listed in the A- and H-share markets, ignoring this feature may result in misspecifications and thus biased estimation results.

7 In addition, the relative weights of the exposure of a firm's A- and H-share returns to the Hong Kong market portfolio and the Chinese market portfolio are found to be generally different. 
For the exchange rate sensitivity, $\beta_{n}^{X}$, earlier empirical studies generally assumed that firms' equity returns only depend on contemporaneous changes in exchange rates. However, empirical evidence by Amihud (1994), Bartov and Bodnar (1994), and Walsh (1994) suggest that there is a lagged relation between changes in exchange rates and firm values due to mispricing. Bartov and Bodnar (1994) formulate the Lagged Response Hypothesis and conjecture that investors may have difficulties in characterising the relation between changes in exchange rates and firm performances, and thus equity values, if time series data are limited. The Lagged Response Hypothesis may therefore be relevant to Chinese firms in general, and Chinese banks in particular, as the exchange regime in China was only switched in July 2005 and the time span available for either investors or bank staff to obtain the relevant information necessary for understanding the relation between changes in the renminbi exchange rate and banks' performance is short.

To incorporate relevant theoretical considerations and empirical evidence, we modify Equation (1) and consider the following empirical specifications for dual-listed Chinese bank stocks,

$$
\begin{aligned}
R_{n, t}-R F_{t}= & \alpha_{n}+\beta_{n}^{C H}\left(R_{C H, t}-R F_{C H, t}\right)+\beta_{n}^{H K}\left(R_{H K, t}-R F_{H K, t}\right) \\
& +\beta_{n}^{C H, A}\left(R_{C H, t}-R F_{C H, t}\right) D u m_{A}+\beta_{n}^{H K, A}\left(R_{H K, t}-R F_{H K, t}\right) D_{u m} \\
& +\beta_{n}^{I} I_{t}+\sum_{j=0}^{J} \beta_{j, n}^{X} X_{t-j}+\delta_{n}^{Z} Z_{t}+\beta_{n}^{A} \operatorname{Dum}_{A}+\varepsilon_{n, t}
\end{aligned}
$$

where $R_{n, t}$ and $R F_{t}$ are the holding period rate of return of the $n^{\text {th }}$ bank stock shares, either A-shares (in terms of the renminbi) or H-shares (in terms of the Hong Kong dollar), from $t-1$ to $t$ and the risk-free interest rate of the market that the bank is listed in, respectively. $\left(R_{C H, t}-R F_{C H, t}\right)$ is the excess return of the Chinese market portfolio, while $\left(R_{H K, t}-R F_{H K, t}\right)$ is the excess return of the Hong Kong market portfolio. Dum ${ }_{A}$ is a 
dummy variable defined as 1 if the observations are from the Chinese stock market (i.e., banks' A-share equity returns), and 0 if the observations are from the Hong Kong stock market (i.e., banks' H-share equity returns). The inclusion of the above market risk related explanatory variables basically follows the spirit of the asset pricing model for dual-listed firms by Alexander et al. (1987) and the empirical evidence by Wang and Jiang (2004). By definition, $\beta_{n}^{C H}+\beta_{n}^{C H, A}$ and $\beta_{n}^{H K}+\beta_{n}^{H K, A}$ are the market sensitivities of the excess returns of the Chinese bank's A-shares to the excess returns of the Chinese market portfolio and that of the Hong Kong market portfolio, respectively, while $\beta_{n}^{C H}$ and $\beta_{n}^{H K}$ are the market sensitivities of the excess returns of a Chinese bank's H-shares to the excess returns of the Chinese market portfolio and that of the Hong Kong market portfolio, respectively.

To estimate interest rate sensitivities, $\beta_{n}^{I}$, we include an explanatory variable in the estimation equation, namely, the rate of change in the yield of risk-free bonds $\left(I_{t}\right){ }^{8}$ This specification is consistent with the Maturity Mismatch Hypothesis by Flannery and James (1984) and facilitates the estimation of the sensitivities of Chinese banks' performance to changes in risk-free interest rates in China.

Regarding the foreign exchange exposure of Chinese banks, it is estimated through the terms $\sum_{j=0}^{J} \beta_{j, n}^{X} X_{t-j}$. This specification assumes that excess returns of Chinese banks are a function of contemporaneous and lagged exchange rates (up to the $J^{\text {th }}$ lagged period), which is consistent with the Lagged Response Hypothesis by Bartov and Bodnar (1994). Under the specification in Equation (2), foreign exchange exposure of the $n^{\text {th }}$ Chinese bank,

8 This is proxied by the rate of change in the yield of 5-year Chinese government bonds. 
$\beta_{n}^{X}$, is defined as $\sum_{j=0}^{J} \beta_{j, n}^{X}$. In this study, $X_{t}$ is defined as the percentage change of the renminbi exchange rate, which is defined as the US dollar value of a unit of the renminbi. 9,10 An increase in the exchange rate implies an appreciation of the renminbi, and vice versa. Hence, a negative (positive) $\beta_{n}^{X}$ suggests that an appreciation of the renminbi would generate negative (positive) impacts on the expected future cash flow of the $n^{\text {th }}$ Chinese bank, and may therefore reduce (increase) its equity returns.

H-share equity returns are expressed in terms of the Hong Kong dollar (rather than the renminbi as in the calculations of A-share equity returns), thus there may be an exchange rate effect on the $\mathrm{H}$-share equity returns due to the exchange rate movements of renminbi exchange rate against the Hong Kong dollar. To control for this possible exchange rate effect for the $\mathrm{H}$-share equity returns, we include a control variable, $Z_{t}$, in Equation (2), which is defined as the percentage change of the renminbi exchange rate against the Hong Kong dollar ${ }^{11}$ for $\mathrm{H}$-share observations and zero otherwise. A similar treatment is adopted by Wang and Jiang (2004) to account for the renminbi-Hong Kong dollar exchange rate effect on the equity return differentials between the A- and $\mathrm{H}$ - shares.

$9 \quad X_{t}$ could also be defined as the renminbi exchange rate against currencies other than the US dollar (e.g., the renminbi exchange rate against the Japanese Yen). In the literature, when different pairs of exchange rates are considered, estimations are usually performed separately for each pair of exchange rate. In this study, we focus on the renminbi exchange rate against the US dollar, as most discussions in the academe and media regarding China's exchange rate movements focus on the renminbi exchange rate against the US dollar. Nevertheless, the foreign exchange exposures of Chinese banks in terms of the renminbi exchange rate against the Japanese Yen and the Euro were also examined. Empirically, we find that larger Chinese banks in general are not significantly exposed to the risk of the renminbi exchange rate against the Japanese Yen and the Euro. Therefore, implications of the foreign exchange exposure arising from changes in the renminbi exchange rate against the Euro or the Japanese Yen for the Chinese banking sector may not be very significant. Detailed results are made available upon request.

10 Conventionally, the renminbi exchange rate is quoted as the renminbi value of a unit of the US dollar. We use its inverse in this study mainly for convenience in interpreting the estimated coefficients of $X_{t}$. It should be noted that defining the renminbi exchange rate reciprocally would only affect the sign of the estimated coefficients of $X_{t}$.

11 Defined as the renminbi value of a unit of the Hong Kong dollar. 
We also include the dummy variable $\operatorname{Dum}_{A}$ in the estimations to capture any structural difference between the excess returns of banks' A-shares and H-shares.

For Chinese banks that are listed only in the Chinese stock market, we adopt the following empirical specification,

$$
R_{n, t}-R F_{t}=\alpha_{n}+\beta_{n}^{C H}\left(R_{C H, t}-R F_{C H, t}\right)+\beta_{n}^{I} I_{t}+\sum_{j=0}^{J} \beta_{j, n}^{X} X_{t-j}+\varepsilon_{n, t}
$$

Equation (3) can be regarded as a simplified version of Equation (2), with the regressors related to the excess return of the Hong Kong market portfolio $\left(R_{H K, t}-R F_{H K, t}\right)$ being excluded from estimations. The adoption of such a specification for locally listed Chinese banks is justified by the fact that locally listed firms in general should be significantly exposed to risk in the local market only.

\section{DATA AND Estimation Method}

We employ in the estimation a panel dataset that contains 14 listed Chinese banks. Of these, three are state-owned commercial banks, ${ }^{12}$ eight are joint-stock commercial banks, ${ }^{13}$ and the remaining three are city-commercial banks. ${ }^{14}$ In terms of asset size, the sample banks together account for over $55 \%$ of total assets of the Chinese banking

12 These include Industrial and Commercial Bank of China, China Construction Bank, and Bank of China.

13 These include Bank of Communications, China Merchants Bank, China CITIC Bank, Shanghai Pudong Development Bank, China Minsheng Bank, Industrial Bank, Huaxia Bank, and Shenzhen Development Bank.

14 These include Bank of Beijing, Bank of Nanjing, and Bank of Ningbo. 
industry as of end-2006. Therefore, the sample should be adequate to give a representative picture of the market.

The data set contains daily equity price data of the 14 Chinese banks for the period of 21 July 2005 to end-February 2008, with the data availability varying across individual banks due to their different dates of initial public offerings (IPOs). The sample starting date is chosen to be 21 July 2005, the day the structural change of China's exchange rate regime took place. ${ }^{15}$ Extending the starting date of the sample to an earlier date may not be desirable because (1) the renminbi exchange rate against the US dollar was virtually unchanged before that date, which may result in biased estimation results, and (2) the majority of the 14 Chinese banks were only listed after 21 July $2005 .^{16}$

Although using daily equity price data can help remedy the problem of insufficient empirical observations in the study of Chinese banks, one drawback is that the dataset may contain some outliners, which could arise from either sudden changes in market sentiments or some special events of the banks (such as sharp rises in prices in the first trading day after IPOs). Including these outliners in the sample may lead to biased results, as the estimations could be unduly affected by them. As such, observations with an excess daily return lower than the $1^{\text {st }}$ percentile or higher than the $99^{\text {th }}$ percentile of the data for each bank are excluded from the sample for estimations.

Of the 14 Chinese banks, six are dual-listed in both the Chinese and Hong Kong stock markets. In constructing the estimation sample, we utilise their daily equity price

\footnotetext{
15 Shifting from de facto pegging the renminbi exchange rate to the US dollar to determining the renminbi exchange rate based on market supply and demand conditions with reference to a basket of currencies.

16 In fact, only 5 of the 14 listed banks were listed in the A-share market before 21 July 2005. They are China Merchants Bank, Shanghai Pudong Development Bank, China Minsheng Bank, Huaxia Bank, and Shenzhen Development Bank.
} 
data for both their A- and H-shares. For the remaining eight Chinese banks, which are purely locally listed, all observations are constructed using their A-share equity data.

Regarding data for the explanatory variables, the daily returns of the Chinese market portfolio, $R_{C H, t}$, are approximated by the weighted average return of the Shanghai Stock Exchange A-Share Index and the Shenzhen Stock Exchange A-Share Index, where the weights at day $t$ are calculated using their respective market capitalisations. The riskfree interest rate in China is proxied by the five-year yield of Chinese government bonds. ${ }^{17}$ The daily returns of the Hong Kong market portfolio, $R_{H K, t}$, is approximated by the Hang Seng Index. We use the five-year yield of Exchange Fund Notes to proxy for the risk-free interest rate in Hong Kong, $R F_{H K, t}$. For the daily percentage changes of China's risk-free interest rate $\left(I_{t}\right)$, we calculate it using the five-year yield of Chinese government bonds. For the daily percentage of appreciation in the renminbi exchange rate against the US dollar, $X_{t-j}$, it is calculated by the corresponding renminbi spot rates. A similar calculation is applied to $Z_{t}$. All data used in this study, including the equity price data of Chinese banks, are obtained from Bloomberg.

We estimate foreign exchange exposure and other risk parameters for each duallisted and locally listed Chinese banks through the Ordinary Least Squares (OLS) method using the empirical specification in Equations (2) and (3), respectively. ${ }^{18}$ For dual-listed

17 We consider three different maturities for the yield of risk-free government bonds. They are the yields of 1-year, 5-year, and 10-year government bonds in China. It is found that the data for 1-year and 10year government bonds' yields are not frequently updated in the early part of the sample period, which may be due to the inactive trading of these two types of bonds. As a result, the yield of 5-year government bonds is chosen.

18 Alternatively, a system of regressions using the Seemingly Unrelated Regression (SUR) method, which is essentially a generalised least squares method accounting for the existence of contemporaneous correlation among equations, can be employed to estimate foreign exchange exposure of the 14 Chinese 
Chinese banks, the problem of heteroskedasticity may exist because the sample is constructed using both their A- and H-share prices. Therefore, $t$-statistics reported for the dual-listed Chinese banks are derived based on the method proposed by White and Domowitz (1984) to accommodate for the heteroskedasticity problem.

In order to obtain the optimal model for each bank, we first run all possible regressions that utilise all combinations of the regressors. Among the estimated regression models, we select the optimal model for each bank using the Akaike (1973) information criterion, a widely applied model selection criterion in the literature. However, this model selection method becomes impractical for a large number of explanatory variables; thus, we set the maximum number of lags for $X_{t}$ to be 5 (i.e., $J=5$ in Equations (2) and (3)) so that the number of explanatory variables is limited to 12 .

\section{ESTIMATION RESULTS}

Estimation results for dual-listed and locally listed Chinese banks are presented in

Tables 1 and 2, respectively. Main findings are as follows:

1. Empirical evidence suggests that there is a significant relationship between bank size (as measured by total assets) and overall foreign exchange exposure

banks jointly. Theoretically, the SUR method could significantly improve the efficiency of the estimates if (1) the contemporaneous correlation among equations is large and can be estimated accurately, and (2) the correlation among regressors in different equations is small (See p.452, Judge et al. (1988)). We may not be able to estimate the contemporaneous correlation among the 14 Chinese banks accurately because the number of observations for some Chinese banks is rather small, in particular, the three city-commercial banks. The efficiency gains of using the SUR method may thus be very limited. Therefore, we adopt the OLS method in this study. Nevertheless, we use the SUR method to estimate the foreign exchange exposure for each dual-listed Chinese bank, as their A- and H-shares should exhibit a significant contemporaneous correlation, and the efficiency gains of using the SUR method may be more significant. However, the foreign exchange exposure estimates obtained using the SUR method turn out to be similar to those obtained from the OLS method. Detailed results are made available upon request. 
(which includes all direct and indirect exposures) in terms of either the significance or the magnitude of the estimated $\beta_{n}^{X}$ :

(a) For the former, larger banks - state-owned commercial banks and jointstock commercial banks - are found more likely to have a significant foreign exchange exposure, either positive or negative, than their smaller counterparts - city-commercial banks. Reflecting this, two of the three state-owned commercial banks and four of the eight jointstock commercial banks in the sample are estimated to have significant foreign exchange exposure (i.e., either a positive or a negative $\beta_{n}^{X}$ ), while only one of the three city-commercial banks is estimated to have significant foreign exchange exposure.

(b) Regarding the magnitude of the estimated $\beta_{n}^{X}$ (measured by its absolute value), it tended to be larger for larger banks. As a group, the stateowned commercial banks, comprising the three largest banks in the sample, have an average magnitude of about 1.3237. The corresponding value for the group of joint-stock commercial banks, composed of eight smaller banks, is 0.5382 , while that of the group of city-commercial banks, the smallest banking group, is only $0.0274 .{ }^{19}$ This suggests that the resulting volatility on equity values due to renminbi exchange rate movements, either an appreciation or a depreciation, tended to be larger for larger banks.

19 The result is even stronger when only those banks with non-zero $\beta_{n}^{X}$ are included. Calculating on this basis, the average foreign exchange exposure of state-owned commercial banks, joint-stock commercial banks, and city-commercial banks is $1.9856,1.0764$, and 0.0821 , respectively. 
(c) (a) and (b) may be partly due to the fact that larger banks tend to have larger foreign exchange trading positions and more significant foreign exchange operations through either their overseas branches, subsidiaries, or joint-ventures with foreign financial institutions. At the same time, because they also tend to have more businesses with large and international corporations, the competitiveness and profitability of which are sensitive to exchange rate movements, the significant foreign exchange exposure of larger Chinese banks may arise from this macrochannel that transmits foreign exchange risk to banks via impacts of the renminbi exchange rate movements on the banks' customers. In addition, foreign exchange regulations on commercial banks in China are also important contributing factors. In particular, each bank that qualifies for business of purchase and sale of foreign exchange in China has an allowable foreign exchange working position (FEWP) approved by the State Administration of Foreign Exchange (SAFE), with the approved FEWPs of individual banks being larger for larger banks. The banks are required to manage their respective FEWPs within the limit set by SAFE on a daily basis, and they have to convert the FEWPs into the US dollar by the end of each business day. ${ }^{20}$ Therefore, in essence, commercial banks in China tend to have positive US dollar exposure in their operations, with larger banks being more likely to have larger positions. $^{21}$

\footnotetext{
For details of the relevant regulations, see chapter three, 'Management of Allowable Foreign Exchange Working Positions', of the People's Bank of China (2002).

21 This is consistent with the fact that Chinese banks tend to have negative estimated foreign exchange exposure, which suggests that an appreciation of the renminbi against the US dollar tends to generate negative impacts on banks' values (this will be discussed later in points (3) and (4) of this section).
} 
2. To gauge the relative size of the foreign exchange exposure of Chinese banks, we also estimate for comparison the foreign exchange exposure for a group of 12 listed banks in Hong Kong, using the same specification in Equation (3) but replacing $\left(R_{C H, t}-R F_{C H, t}\right)$ and $I_{t}$ with their Hong Kong counterparts. ${ }^{22}$ Such a model specification attempts to reveal how banks in Hong Kong are exposed to the risk of the renminbi exchange rate movements against the US dollar, with $X_{t}$ defined as the daily percentage appreciation in the renminbi exchange rate against the US dollar. It should be noted that such a comparison is subject to significant caveats given the significant differences between Chinese banks and Hong Kong banks. ${ }^{23}$

(a) The results show that the average magnitude of foreign exchange exposure of banks in Hong Kong is 0.4264 . This is significantly lower than the 1.3237 magnitude for the three state-owned commercial banks and the 0.5382 magnitude for the eight joint-stock commercial banks in China. In contrast, the average magnitude of foreign exchange exposure of the three city-commercial banks (0.0274) is smaller than that of Hong Kong banks. This suggests that larger Chinese banks are in general exposed more to the risk of renminbi exchange rate movements against the US dollar than either banks in Hong Kong or their smaller counterparts in China.

22 The sample includes Bank of China (HK), Bank of East Asia, Chong Hing Bank, CITIC Ka Wah Bank, Dah Sing Bank, Fubon Bank, Hang Seng Bank, HSBC, ICBC (Asia), Standard Chartered Bank, Wing Hang Bank, and Wing Lung Bank. We also estimate the average foreign exchange exposure of Hong Kong banks by excluding two of the larger banks, namely, HSBC and the Standard Chartered Bank from the sample, as they are to a large extent more internationalised and have significantly different asset compositions from other Hong Kong banks. The average magnitude of foreign exchange exposure thus estimated turned out to be very similar to the result obtained using the complete sample.

23 For example, in the context of foreign exchange businesses, banks in Hong Kong in general would have a larger autonomy with regard to business strategies and operations than banks in China. 
(b) Even when $X_{t}$ in the estimation of Hong Kong banks is replaced by the daily percentage change of the Hong Kong dollar trade-weighted effective nominal exchange rate index $\left(E E R I_{t}\right)$, which is a broader definition of exchange rate movements, the average magnitude of foreign exposure of banks in Hong Kong, estimated to be 0.6459 , is still significantly lower than that of state-owned banks.

(c) It is not apparent why the foreign exchange exposure of Chinese banks as estimated is larger than that of Hong Kong banks, particularly given that the participation of Chinese banks in international banking businesses should still be limited when compared with Hong Kong banks. It is, however, possible that the estimated larger foreign exchange exposure of Chinese banks may reflect the lack of financial instruments available in the local market to hedge their foreign exchange risk or perhaps their lack of experience in managing foreign exchange risk.

3. Consistent with past empirical findings for other banking markets, foreign exchange exposure tends to be different among Chinese banks. Of the 14 listed Chinese banks, five are estimated to have a negative $\beta_{n}^{X}$, suggesting that an appreciation of the renminbi against the US dollar tends to generate negative impacts on banks' values. On the other hand, two banks are estimated to have positive $\beta_{n}^{X}$, which indicates the opposite, while the remaining seven are estimated to have no significant foreign exchange exposure. 
4. To the extent that foreign exchange exposure tends to be different among Chinese banks, negative foreign exchange exposures are more prevalent for larger Chinese banks, suggesting that an appreciation of the renminbi tends to reduce their equity values. Specifically, we find that an appreciation of the renminbi by $1 \%$ would, on average, reduce the excess equity returns for larger banks - state-owned commercial banks by $1.32 \%$ and joint-stock commercial banks by $0.35 \%$ - but may boost the excess equity returns for smaller banks (city-commercial banks) by $0.03 \% .^{24}$ On the whole, since the state-owned and joint-stock commercial banks constitute more than $67 \%$ of assets in the Chinese banking market (as of end-2006) ${ }^{25}$, an appreciation of the renminbi is likely to hamper the Chinese banking sector's performance.

Empirical findings other than foreign exchange exposure of Chinese banks are summarised as follows.

5. For dual-listed Chinese banks, their A-shares are found to be affected more by the returns of the Chinese market portfolio than the Hong Kong market portfolio, which is consistent with empirical findings by Wang and Jiang (2004). Specifically, the performance of the Chinese market appears to be an

24 State-owned commercial banks, on average, are estimated to have a larger negative foreign exchange exposure compared with the two smaller banking groups. This should be partly attributed to the capital injections by the China SAFE Investment Limited ('Huijin') to the state-owned commercial banks. Huijin has used US\$ 60 billion of its foreign reserves to boost the capital of the three listed state-owned banks since 2004. Under the arrangement, the injected US dollar capital is not allowed to convert directly to the renminbi in the foreign exchange market. To hedge the foreign exchange risk, the banks entered into foreign currency option agreements with Huijin in January 2005 with respective notional amounts similar to the foreign exchange positions arising from the capital injections. However, it was not until 2007 that Bank of China and China Construction Bank exercised their foreign currency options. For Industrial and Commercial Bank of China, no option had been exercised by the end of 2007. For details, see the banks' annual reports of 2007.

25 According to the People's Bank of China (2007), as of end-2006, the total asset values of state-owned commercial banks, joint-stock commercial banks, and the banking sector as a whole are RMB 24,236 billion, RMB 5,445 billion, and RMB 43,950 billion, respectively. 
important factor in determining the performance of Chinese banks' A-shares. The estimated market risk sensitivity ranges from 0.6818 to $0.8658 .^{26}$ In contrast, Chinese banks' A-share equity returns are exposed only by a limited degree to the Hong Kong market risk, as suggested by their estimated sensitivities to the Hong Kong market portfolio, which are relatively small in general (ranging from 0.0760 to 0.2501$).{ }^{27}$ For banks' H-share returns, duallisted Chinese banks are found to be exposed to Hong Kong's market risk, with the estimated coefficient of the excess returns of the Hong Kong market portfolio, $\beta_{n}^{H K}$, being statistically significant at the $1 \%$ confidence level for all dual-listed Chinese banks and the estimates ranging from 0.6889 to 1.1645 . However, they are in general not significantly exposed to the risk of the Chinese market portfolio.

6. Regarding interest rate sensitivity of Chinese banks, 9 out of the 14 Chinese banks are estimated to have significant and negative interest rate exposure (i.e., negative $\beta_{n}^{I}$ ). This result is consistent with empirical results in the US banking market by Choi and Elyasiani (1997), who find that not all US commercial banks are exposed to a significant interest rate risk. ${ }^{28}$ This suggests that increases in interest rates tend to reduce banks' equity values. In addition, smaller banks, particularly the three city-commercial banks, are found to have higher interest rate sensitivities. This suggests that monetary tightening in

26 Note that it refers to $\left(\beta_{n}^{C H}+\beta_{n}^{C H, A}\right)$ for dual-listed Chinese banks.

27 It refers to $\left(\beta_{n}^{H K}+\beta_{n}^{H K, A}\right)$.

28 Choi and Elyasiani (1997) found that while 59 large US commercial banks as a whole are estimated to have significant interest rate exposure, only 23 are found to have significant interest rate exposure individually. 
general produce negative impacts on Chinese banks, with the effect on smaller banks being more pronounced. ${ }^{29}$

\section{Conclusion}

Using the equity price data of 14 listed Chinese banks, this study adopts the capital market approach to examine Chinese banks' foreign exchange exposure, which comprises the direct exposure arising from banks' unhedged foreign assets and liabilities and the indirect exposure due to effects of exchange rate movements on cash flows, and credit risk of the banks' customers.

Empirical evidence suggests that there is a positive relationship between bank size and foreign exchange exposure. This may be partly due to the fact that larger banks tend to have more significant foreign exchange operations and trading positions. Larger banks may also have more businesses with large and international corporations, the competitiveness and profitability of which are sensitive to exchange rate movements. Foreign exchange regulations should also contribute to the more significant foreign exchange exposure of larger Chinese banks.

In addition, the average foreign exchange exposures of state-owned and joint-stock commercial banks in China are higher than those of banks in Hong Kong, notwithstanding

29 This empirical finding is consistent with financial news relating to the Chinese banking market. For example, South China Morning Post (10 March 2008) reported that under strict rules on bank lending in 2008, 'Small city-commercial banks, already struggling to boost deposit levels, have been hit the hardest, prompting them to look for partnerships or consolidation while their customers are left scrambling for financing'. This indicates that smaller banks tend to suffer more significantly than larger banks in the phase of monetary tightening. 
their still limited participation in international banking businesses compared with their Hong Kong counterparts. This may reflect the lack of financial instruments available for Chinese banks to hedge their foreign exchange risk, or that the banks were less experienced in managing foreign exchange risk.

It is also found that foreign exchange exposure tends to be different among Chinese banks, with negative foreign exchange exposure more prevalent for larger Chinese banks, suggesting that an appreciation of the renminbi tends to reduce their equity values. Larger banks constitute a major portion of assets in the Chinese banking industry; hence, this empirical result suggests that an appreciation of the renminbi is likely to hamper the Chinese banking sector's performance.

The empirical results suggest that an appreciation of the renminbi will likely have a negative impact on the performance, and thus the equity values, of Chinese banks, with the impacts on larger banks being more pronounced. Together with the fact that decreases in equity values generally imply a higher default risk, the effects of different scenarios of renminbi appreciation on the default risk of Chinese banks should therefore be closely monitored. 


\section{Reference:}

Aharony, J., and Swary, I., 1983. Contagion Effects of Bank Failures: Evidence from Capital Markets, Journal of Business 56(3), 305--22.

Akaike, H., 1973. Information Theory and the Extension of the Maximum Likelihood Principle, in: Petrov, B.N., and Csaki, F. (Eds.), Proceedings of Second International Symposium on Information Theory. Akedemiai Kiado, Budapest, 267--287.

Alexander, G. J., Eun, C. S., and Janakiramanan, S., 1987. Asset Pricing and Dual Listing on Foreign Capital Markets: A Note, Journal of Finance 42(1), 151--58.

Amihud, Y., 1994. Evidence on Exchange Rates and Valuation of Equity Shares, in: Amihud, Y. and Levich, R. M. (Eds.), Exchange Rates and Corporate Performance. Irwin, Homewood, IL, 49--59.

Atindéhou, R. B. and Gueyie, J. P., 2001. Canadian Chartered Banks' Stock Returns and Exchange Rate Risk, Management Decision 39(4), 285--95.

Bae, S. C., 1990. Interest Rate Changes and Common Stock Returns of Financial Institutions: Revisited, Journal of Financial Research 13(1), 71--9.

Bartov, E. and Bodnar, G. M., 1994. Firm Valuation, Earnings Expectations, and the Exchange-rate Exposure Effect, Journal of Finance 49(5), 1755--85.

Basel Committee on Banking Supervision, 1996. Amendment to the Capital Accord to Incorporate Market Risks. Basel, Switzerland.

Chamberlain, S., Howe, J. S., and Popper, H., 1997. The Exchange Rate Exposure of U.S. and Japanese Banking Institution, Journal of Banking and Finance 21(6), 871--92.

Chen, C. R. and Chan, A., 1989. Interest Rate Sensitivity, Asymmetry, and the Stock Returns of Financial Institutions, Financial Review 24(3), 457--73.

Chi, J., Tripe, D., and Young, M., 2007. Do Exchange Rates Affect the Stock Performance of Australian Banks?, paper presented in the $12^{\text {th }}$ Finsia-Melbourne Centre for Financial Studies Banking and Finance Conference, Melbourne, 24-25 September 2007.

Choi, J. J. and Elyasiani, E., 1997. Derivatives Exposure and the Interest Rate and Exchange Rate Risks of U.S. Banks, Journal of Financial Services Research 12(2/3), 267-86.

Choi, J. J., Elyasiani, E., and Kopecky, K. J., 1992. The Sensitivity of Bank Stock Returns to Market, Interest and Exchange Rate Risk, Journal of Banking and Finance 16(5), 983-1004.

De Wet, W. A. and Gebreselasie, T. G., 2004. The Exchange Rate Exposure of Major Commercial Banks in South Africa, The African Finance Journal 6(2), 21--35. 
Flannery, M. J. and James, C. M., 1984. The Effect of Interest Rate Changes on the Common Stock Returns of Financial Institutions, Journal of Finance 39(4), 1141--53.

Grammatikos, T., Saunders, A., and Swary, I., 1986. Returns and Risks of U.S. Bank Foreign Currency Activities, Journal of Finance 41(3), 671--82.

Hahm, J. H., 2004. Interest Rate and Exchange Rate Exposures of Banking Institutions in Pre-crisis Korea, Applied Economics 36(13), 1409--19.

Judge, G., Hill, C., Griffiths, W., Lee, T., and Lutkepol, H., 1988. An Introduction to the Theory and Practice of Econometrics. John Wiley and Sons, New York.

Martin, A. D., 2000. Exchange Rate Exposure of the Key Financial Institutions in the Foreign Exchange Market, International Review of Economics and Finance 9(3), 267--86.

Martin, A. D. and Mauer, L. J., 2003. Exchange Rate Exposures of US Banks: a Cash Flow-based Methodology, Journal of Banking and Finance 27(5), 851--65.

Martin, A. D. and Mauer, L. J., 2005. A Note on Common Methods Used to Estimate Foreign Exchange Exposure, Journal of International Financial Markets, Institutions and Money 15(2), 125--40.

Muller, A. and Verschoor, W. F. C., 2006. Foreign Exchange Risk Exposure: Survey and Suggestions, Journal of Multinational Financial Management 16(4), 385--410.

People's Bank of China, 2002. Provisional Procedures for Designated Bank's Purchase and Sale of Foreign Exchange, available at http://www.pbc.gov.cn/english//detail.asp?col=6800\&ID=33

People's Bank of China, 2007. Almanac of China's Finance and Banking 2007. China

Walsh, E. J., 1994. Operating Income, Exchange Rate Changes, and the Value of the Firm: an Empirical Analysis, Journal of Accounting, Auditing and Finance 9(4), 703--24.

Wetmore, J. L. and Brick, J. R., 1994, Commercial Bank Risk: Market, Interest Rate, and Foreign Exchange, Journal of Financial Research 17(4), 585--96.

Wang, S. S. and Jiang, L., 2004. Location of Trade, Ownership Restriction, and Market Illiquidity: Examining Chinese A- and H-shares, Journal of Banking and Finance 28(6), 1273--97.

White, H. and Domowitz, I., 1984., Nonlinear Regression with Dependent Observations, Econometrica 52(1), 143--61.

Yourougou, P., 1990. Interest-rate Risk and the Pricing of Depository Financial Intermediary Common Stock: Empirical Evidence, Journal of Banking and Finance 14(4), 803--20. 
Table 1: Estimation results of foreign exchange exposure of dual-listed Chinese banks

\begin{tabular}{|c|c|c|c|c|c|c|c|}
\hline $\begin{array}{c}\text { Explanatory } \\
\text { variables }\end{array}$ & Coefficients & $\begin{array}{c}\text { State-owned } \\
\text { commercial bank } 1\end{array}$ & $\begin{array}{c}\text { State-owned } \\
\text { commercial bank } 2\end{array}$ & $\begin{array}{c}\text { State-owned } \\
\text { commercial bank } 3\end{array}$ & $\begin{array}{c}\begin{array}{c}\text { Joint-stock commercial } \\
\text { bank } 1\end{array} \\
\end{array}$ & $\begin{array}{c}\text { Joint-stock commercial } \\
\text { bank } 2\end{array}$ & $\begin{array}{c}\text { Joint-stock commercial } \\
\text { bank } 3\end{array}$ \\
\hline Intercept & $\alpha_{n}$ & $\begin{array}{l}0.0005 \\
(0.69)\end{array}$ & $\begin{array}{c}0.0006 \\
(1.06)\end{array}$ & $\begin{array}{c}-0.0008 \\
(-1.41)\end{array}$ & $\begin{array}{l}0.0007 \\
(1.09)\end{array}$ & $\begin{array}{c}0.0003 \\
(0.50)\end{array}$ & $\begin{array}{c}-0.0018^{* * *} \\
(-2.10)\end{array}$ \\
\hline$R_{H K, t}-R F_{H K, t}$ & $\beta_{n}^{H K}$ & $\begin{array}{c}1.0873 * * * \\
(21.29) \\
\end{array}$ & $\begin{array}{c}1.1645 * * * \\
(24.70) \\
\end{array}$ & $\begin{array}{c}0.8759 * * * * \\
(23.36) \\
\end{array}$ & $\begin{array}{c}1.1215 * * * * \\
(20.30) \\
\end{array}$ & $\begin{array}{c}1.0905 * * * * \\
(20.67) \\
\end{array}$ & $\begin{array}{c}0.6889^{* * * *} \\
(13.19) \\
\end{array}$ \\
\hline$R_{C H, t}-R F_{C H, t}$ & $\beta_{n}^{C H}$ & & & & & & \\
\hline$\left(R_{H K, t}-R F_{H K, t}\right) D_{\text {uum }}$ & $\beta_{n}^{H K, A}$ & $\begin{array}{c}-0.8904 * * * \\
(-11.32) \\
\end{array}$ & $\begin{array}{c}-0.9514 * * * \\
(-10.02) \\
\end{array}$ & $\begin{array}{c}-0.7166^{* * * *} \\
(-11.22)\end{array}$ & $\begin{array}{c}-0.9593 * * * * \\
(-11.05)\end{array}$ & $\begin{array}{c}-0.8404 * * * \\
(-10.56)\end{array}$ & $\begin{array}{c}-0.6129^{\text {**** }}(-7.31) \\
\end{array}$ \\
\hline$\left(R_{C H, t}-R F_{C H, t}\right) D_{u m}$ & $\beta_{n}^{C H, A}$ & $\begin{array}{c}0.7942 * * * \\
(19.63)\end{array}$ & $\begin{array}{c}0.6818^{* * * *} \\
(7.13)\end{array}$ & $\begin{array}{c}0.7271 * * * * \\
(18.52)\end{array}$ & $\begin{array}{c}0.8180^{* * * *} \\
(14.62)\end{array}$ & $\begin{array}{c}0.8269 * * * * \\
(15.94)\end{array}$ & $\begin{array}{c}0.8658 * * * \\
(13.99)\end{array}$ \\
\hline$I_{t}$ & $\beta_{n}^{I}$ & $\begin{array}{c}-0.2073 * * \\
(-2.02) \\
\end{array}$ & $\begin{array}{c}-0.0844 \\
(-1.54) \\
\end{array}$ & & $\begin{array}{c}-0.1043^{* *} \\
(-2.09) \\
\end{array}$ & & $\begin{array}{c}-0.2574 * * * \\
(-2.69) \\
\end{array}$ \\
\hline$X_{t}$ & $\beta_{0, n}^{X}$ & & & & & & \\
\hline$X_{t-l}$ & $\beta_{1, n}^{X}$ & & & $\begin{array}{c}-0.9662 * \\
(-1.90) \\
\end{array}$ & & & \\
\hline$X_{t-2}$ & $\beta_{2, n}^{X}$ & $\begin{array}{c}-1.1641^{* *} \\
(-2.26) \\
\end{array}$ & & $\begin{array}{c}-0.9179 * * \\
(-2.19) \\
\end{array}$ & & & \\
\hline$X_{t-3}$ & $\beta_{3, n}^{X}$ & $\begin{array}{c}-0.9230^{*} \\
(-1.74)\end{array}$ & & & & & \\
\hline$X_{t-4}$ & $\beta_{4, n}^{X}$ & & & & & & \\
\hline$X_{t-5}$ & $\beta_{5, n}^{X}$ & & & & $\begin{array}{c}0.7370 \\
(1.62) \\
\end{array}$ & & \\
\hline$Z_{t}$ & $\delta_{n}^{Z}$ & & & & & & \\
\hline $\operatorname{Dum}_{A}$ & $\beta_{n}^{A}$ & & & & $\begin{array}{c}-0.0020 \\
(-1.34) \\
\end{array}$ & & \\
\hline \multicolumn{2}{|l|}{$\overline{\mathrm{R}^{2}}$} & 0.6168 & 0.5620 & 0.5366 & 0.5197 & 0.4958 & 0.5245 \\
\hline \multicolumn{2}{|l|}{ Adjusted $\mathrm{R}^{2}$} & 0.6129 & 0.5591 & 0.5336 & 0.5158 & 0.4940 & 0.5195 \\
\hline \multicolumn{2}{|l|}{ DW statistics } & 1.8570 & 1.7312 & 2.1209 & 1.7082 & 1.9742 & 2.0690 \\
\hline \multicolumn{2}{|l|}{ Number of observations } & 602 & 619 & 778 & 744 & 840 & 384 \\
\hline \multicolumn{2}{|l|}{$\sum_{j=0}^{J} \beta_{j, n}^{X}$} & $\begin{array}{l}-2.0871 \\
{[0.7858]}\end{array}$ & $\begin{array}{c}0.0000 \\
{[\mathrm{NA}]}\end{array}$ & $\begin{array}{l}-1.8840 \\
{[0.6725]}\end{array}$ & $\begin{array}{c}0.7370 \\
{[0.4543]}\end{array}$ & $\begin{array}{c}0.0000 \\
{[\mathrm{NA}]}\end{array}$ & $\begin{array}{c}0.0000 \\
{[\mathrm{NA}]}\end{array}$ \\
\hline
\end{tabular}

(1) Figures in parentheses are t-statistics. Figures in brackets are standard errors using the Wald test. *,**, and *** denote statistical significance at the $10 \%, 5 \%$, and $1 \%$ levels, respectively.

(2) For each bank, all possible regressions that utilise all combinations of the regressors are estimated first. Among the estimated models for each bank, the optimal model using the Akaike (1973) information criterion is selected and shown in the table. Therefore, the optimal model specification varies across the banks and some explanatory variables that have low explanatory power are not included in the optimal model (i.e., variables with blank coefficient estimates)

(3) The sensitivities of banks' H-share equity returns to Hong Kong and China's market risks are measured by $\beta_{n}^{H K}$ and $\beta_{n}^{C H}$, respectively. The sensitivities of banks' A-share equity returns to Hong Kong and China's market risks are measured by $\left(\beta_{n}^{H K}+\beta_{n}^{H K, A}\right)$ and $\left(\beta_{n}^{C H}+\beta_{n}^{C H, A}\right)$, respectively.

(4) NA: Not applicable. 
Table 2: Estimation results of foreign exchange exposure of locally listed Chinese banks

\begin{tabular}{|c|c|c|c|c|c|c|c|c|c|}
\hline $\begin{array}{l}\text { Explanatory } \\
\text { variables }\end{array}$ & Coefficients & $\begin{array}{c}\text { Joint-stock } \\
\text { commercial } \\
\text { bank } 4\end{array}$ & $\begin{array}{c}\text { Joint-stock } \\
\text { commercial } \\
\text { bank } 5\end{array}$ & $\begin{array}{c}\text { Joint-stock } \\
\text { commercial } \\
\text { bank } 6\end{array}$ & $\begin{array}{c}\text { Joint-stock } \\
\text { commercial } \\
\text { bank } 7 \\
\end{array}$ & $\begin{array}{c}\text { Joint-stock } \\
\text { commercial } \\
\text { bank } 8 \\
\end{array}$ & $\begin{array}{c}\text { City-commercial } \\
\text { bank } 1\end{array}$ & $\begin{array}{c}\text { City-commercial } \\
\text { bank } 2\end{array}$ & $\begin{array}{c}\text { City-commercial } \\
\text { bank } 3\end{array}$ \\
\hline Intercept & $\alpha_{n}$ & $\begin{array}{l}0.0010 \\
(1.04)\end{array}$ & $\begin{array}{l}0.0011 \\
(0.65)\end{array}$ & $\begin{array}{l}0.0008 \\
(0.90)\end{array}$ & $\begin{array}{l}0.0008 \\
(0.84)\end{array}$ & $\begin{array}{c}0.0009 \\
(1.00)\end{array}$ & $\begin{array}{c}-0.0008 \\
(-0.41) \\
\end{array}$ & $\begin{array}{l}-0.0015 \\
(-0.91)\end{array}$ & $\begin{array}{l}-0.0017 \\
(-7773) \\
\end{array}$ \\
\hline$R_{C H, t}-R F_{C H, t}$ & $\beta_{n}^{C H}$ & $\begin{array}{c}0.8843 * * * \\
(16.82) \\
\end{array}$ & $\begin{array}{c}0.9519 * * * \\
(13.11)\end{array}$ & $\begin{array}{c}0.9392^{* * * *} \\
(18.83)\end{array}$ & $\begin{array}{c}1.0271 * * * \\
(18.87)\end{array}$ & $\begin{array}{c}0.8524 * * * \\
(17.24)\end{array}$ & $\begin{array}{c}0.9209^{* * * *} \\
(10.66)\end{array}$ & $\begin{array}{c}0.8409^{* * *} \\
(11.20)\end{array}$ & $\begin{array}{c}0.9861 * * * \\
(10.35)\end{array}$ \\
\hline$I_{t}$ & $\beta_{n}^{I}$ & & $\begin{array}{c}-0.3832 * \\
(-1.67)\end{array}$ & & & $\begin{array}{c}-0.1179^{*} \\
(-1.674)\end{array}$ & $\begin{array}{c}-1.0309 \text { *** } \\
(-3.46)\end{array}$ & $\begin{array}{c}-0.5842^{* * *} \\
(-2.33)\end{array}$ & $\begin{array}{c}-0.9049 * * \\
(-2.91)\end{array}$ \\
\hline$X_{t}$ & $\beta_{0, n}^{X}$ & & & & & & & & \\
\hline$X_{t-1}$ & $\beta_{1, n}^{X}$ & & & & & & & & $\begin{array}{l}-2.4291 \\
(-1.47) \\
\end{array}$ \\
\hline$X_{t-2}$ & $\beta_{2, n}^{X}$ & & & $\begin{array}{l}-0.9976 \\
(-1.53) \\
\end{array}$ & $\begin{array}{c}-1.4089^{*} \\
(-1.90) \\
\end{array}$ & & & & \\
\hline$X_{t-3}$ & $\beta_{3, n}^{X}$ & & & & & & & & \\
\hline$X_{t-4}$ & $\beta_{4, n}^{X}$ & $\begin{array}{r}-1.1619 \\
(-1.53) \\
\end{array}$ & & & & & & & \\
\hline$X_{t-5}$ & $\beta_{5, n}^{X}$ & & & & & & & & $\begin{array}{c}2.5113^{*} \\
(1.47) \\
\end{array}$ \\
\hline \multicolumn{2}{|l|}{$\mathrm{R}^{2}$} & 0.3443 & 0.4135 & 0.3994 & 0.4145 & 0.3405 & 0.5614 & 0.4799 & 0.4896 \\
\hline \multicolumn{2}{|l|}{ Adjusted $\mathrm{R}^{2}$} & 0.3419 & 0.4088 & 0.3972 & 0.4123 & 0.3382 & 0.5526 & 0.4726 & 0.4749 \\
\hline \multicolumn{2}{|l|}{ DW statistics } & 1.8959 & 1.734 & 1.9715 & 1.9107 & 1.8597 & 2.1315 & 1.8320 & 1.8205 \\
\hline \multicolumn{2}{|c|}{ Number of observations } & 544 & 251 & 547 & 520 & 584 & 102 & 146 & 144 \\
\hline \multicolumn{2}{|l|}{$\sum_{j=0}^{J} \beta_{j, n}^{X}$} & $\begin{array}{l}-1.1619 \\
{[0.7569]}\end{array}$ & $\begin{array}{l}0.0000 \\
{[\mathrm{NA}]}\end{array}$ & $\begin{array}{l}-0.9976 \\
{[0.6541]}\end{array}$ & $\begin{array}{l}-1.4089 \\
{[0.7414]}\end{array}$ & $\begin{array}{c}0.0000 \\
{[\mathrm{NA}]}\end{array}$ & $\begin{array}{c}0.0000 \\
{[\mathrm{NA}]}\end{array}$ & $\begin{array}{c}0.0000 \\
{[\mathrm{NA}]}\end{array}$ & $\begin{array}{c}0.0821 \\
{[2.3055]}\end{array}$ \\
\hline
\end{tabular}

(1) Figures in parentheses are t-statistics. Figures in brackets are standard errors using the Wald test. *, **, and *** denote statistical significance at the $10 \%, 5 \%$, and $1 \%$ levels, respectively.

(2) For each bank, all possible regressions that utilise all combinations of the regressors are estimated first. Among the estimated models for each bank, the optimal model using the Akaike (1973) information criterion is selected and shown in the table. Therefore, the optimal model specification varies across the banks and some explanatory variables that have low explanatory power are not included in the optimal model (i.e., variables with blank coefficient estimates).

(3) NA: Not applicable 